\title{
Factors Reducing Efficiency of the Operational Oceanographic Forecast Systems in the Arctic Basin
}

\author{
V.N. Belokopytov \\ Marine Hydrophysical Institute, Russian Academy of Sciences, Sevastopol, Russian Federation \\ e-mail: v.belokopytov@gmail.com
}

Reliability of the forecasted fields in the Arctic Basin is limited by a number of problems resulting, in the first turn, from lack of operational information. Due to the ice cover, satellite data on the sea level and the sea surface temperature is either completely not available or partially accessible in summer. The amount of CTD measuring systems functioning in the operational mode (3-5 probes) is not sufficient. The number of the temperature-profiling buoys the probing depth of which is limited to $60 \mathrm{~m}$, is not enough for the Arctic as well. Lack of spatial resolution of the available altimetry information (14 $\mathrm{km})$, as compared to the Rossby radius in the Arctic Ocean $(2-12 \mathrm{~km})$, requires a thorough analysis of the forecasting system practical goals. The basic factor enhancing reliability of the oceanographic forecast consists in the fact that the key oceanographic regions, namely the eastern parts of the Norwegian and Greenland seas, the Barents Sea and the Chukchi Sea including the Bering Strait (where the Atlantic and Pacific waters flow in and transform, and the halocline structure is formed) are partially or completely free of ice and significantly better provided with operational information.

Keywords: Arctic, operational oceanography, ocean monitoring, thermohaline structure.

DOI: 10.22449/1573-160X-2017-2-19-24

(C) 2017, V.N. Belokopytov

(C) 2017, Physical Oceanography

Introduction. Homeland practice of marine forecasts in the Arctic has a long history related to the development and maintenance of the Northern Sea Route. First of all, it applies to the ice forecasts which are traditionally dealt with by Arctic and Antarctic Research Institute (AARI). Currently short-term forecasts of the World Ocean water circulation and hydrological fields, including the Arctic Basin, became widely available. Among the foreign examples we can mention Copernicus Marine Environment Monitoring Service which contains an arctic block based on HYCOM model, performing 10-day cycle of forecast with $12.5 \mathrm{~km}$ spatial resolution every day, and a global block based on NEMO model with $1 / 12^{\circ}$ resolution. In Russia for these purposes the operational module ESIMO "Analysis of hydrophysical fields in the ocean" of Roshydromet has been developed (and it is still functioning). The possibility of applying the complete models of the ocean circulation in the operational practice became real due to development of the Arctic Ocean regional models [1 - 5]. In comparison with other areas of the World Ocean, the increase in the reliability of the forecasted fields in the Arctic Basin is limited by a number of varying complexity problems primarily related to the lack of operational information.

Operational oceanographic information. Satellite oceanographic information on the ocean level and sea surface temperature widely used in operational models is either completely inaccessible throughout most of the Arctic Basin due to the presence of ice cover, or is only available in the summer season. Information on 
water temperature is very often limited due to the presence of cloudiness even in the absence of the ice.

The absence of regular information on river runoff into the arctic seas when using diagnostic models is usually compensated by climatic annual mean and seasonal values. But for an operational forecast, especially for the shelf and continental slope, this is obviously not enough, taking into account a very significant runoff of the rivers (comparable to the most moistened equatorial regions) and its significant temporal variability.

The assimilation of current hydrological information in operational ocean forecast systems is largely based on the operation of Argo buoys [6]. In the Norwegian and Greenland Seas the density of coverage by the Argo system is comparable to other areas of the ocean but only separated buoys get into the Arctic Basin, the Barents Sea or to the northern coast of Spitsbergen due to water circulation features. A similar situation takes place in the Amerasian Basin where the Argo buoys usually move only in limited by the deep-water part of the Bering Sea.

The deployment of standard Argo buoys directly in the Arctic Basin will inevitably results in a rapid loss of communication with them. Therefore, the information on water surface layer temperature values and buoy coordinates from the surface drifters of SVP, DB, PAW, IABP, ICEBALL, AXIB etc. types [7] is the most available to date.

The first versions of the modified Argo buoys that were rigidly fixed in the ice (Salargos Buoy, Polar Ocean Profile Buoy) appeared in 1985 - 1994. Within the framework of different international programs, such as International Arctic Buoy Programme, new systems were developed: Polar Ocean Profiling System (POPS) with down to $1000 \mathrm{~m}$ probing, Ice-Tethered Profiler (ITP) operating down to 500 800 m depths, Ice-Atmosphere-Arctic Ocean Observing System (IAOOS) applied at "Barneo" Russian drifting station. However, the number of such measuring stations functioning in the operational mode is very small - no more than $3-5$ buoys are simultaneously located in the Arctic. For instance, 7 - 10 Argo buoys are simultaneously located in the Black Sea the area of which is $20-30$ times smaller than the one of the Arctic Basin.

A distinct contribution to the increase of the volume of operational information on vertical profiles can be made by temperature-profiling drifters (their maintenance is supported within the framework of UpTempO international program [8]) including the buoys producing in Marine Hydrophysical Institute of RAS. Their advantages consist in lower production cost in comparison with Argo-type buoys and in increased temporal discreteness of measurements. The disadvantages include the fact that cable length is limited to $60 \mathrm{~m}$, and the addition of a conductivity (salinity) sensor has not been implemented yet. The number of simultaneously operating temperature-profiling buoys in the Arctic is as small as the one of CTDbuoys.

A certain potential lies in the further development of Voluntary Observing Ship (VOS) international program with the use of XBT and XCTD expendable probes and FerryBox-type flow-through system (GOSUD program [10]). At the present time the information from the Arctic Basin within the framework of this system comes only from the Beaufort Sea and the Chukchi Sea during the naviga- 
tion in the waters of Alaska. There is a potential prospect for increasing this data flow by using sea transport on the Northern Sea Route as well as in tourist cruises.

Also it should be pointed out that apart from the lack of oceanographic information additional difficulties for forecasting in the Arctic appear due to necessity of ice block selection for the general model. The assessments of many physical processes (ice formation/melting, ice-modified tangential stress of wind friction, haline convection intensity, etc.) depend on realization of sea ice cover thermodynamic model which takes into account the snow cover and ice thermodynamics and rheology. The absence of information on all required ice parameters, after all the progress of the ice cover monitoring satellite methods, increases the ambiguity of the results of general coupled model calculations.

Consideration of the Arctic hydrologic structure features. Taking into account the complexities of wide monitoring system deployment in the Arctic region, a question about the very possibility of reliable operational forecasts in terms of a lack of information arises. Therefore, it makes sense to consider the potential availability of information in key areas which are important for the formation of thermohaline structure in the basin as a whole.

The concepts of the Arctic oceanography originating from the works of F. Nansen were developed by the Soviet school of arctic research and are constantly refined in the modern period within the framework of various international projects [2, 3, $11-19]$. The most familiar external factor of the ones forming oceanographic characteristics of a basin is the inflow of the Atlantic (warm and saline) and the Pacific (freshened) waters in the form of well-pronounced jet streams. Another distinctive feature of the Arctic hydrology is a key role of salinity in vertical stratification of waters. This is related to the large inflow of fresh water due to river runoff and seasonal melting of ice as well as to predominant effect of salinity variation on the density at low water temperature. A complex system of halocline in different parts of the basin is largely related to the advection of diluted waters from the certain geographical regions.

Direct measurements of the discharges of two branches of incoming Atlantic water, which are regularly performed in the Fram Strait and in the south-western part of the Barents Sea, have not yet become publicly available part of the operational monitoring system. Moreover, the assessments of these water inflow volumes in the literature have a rather wide spread due to the complexity of recirculation and synoptic variability. Boundary conditions of water exchange for operational models can be specified from the calculations for global or regional models of the Norwegian Sea which are well provided with altimetric and hydrological information. The Bering Strait narrowness and shallowness provide the opportunity to assess the flow of the Pacific waters by the difference in sea level between the oceans but only in that period when the ice in the Chukchi and the Bering Seas is absent.

One of the areas for the intermediate layer halocline formation is located in the Nansen Basin where during the winter convection a mixed layer is formed from the modified Atlantic waters of the Fram Strait branch. For the period of convection thermal stage there is a possibility to use satellite information on sea surface temperature up to the beginning of ice formation. Complete picture of convection de- 
velopment can be obtained only with the use of $C T D$-buoys as the sickness of the mixed layer reaches $100 \mathrm{~m}$ and temperature-profiling drifters have limitations on the probing depth.

Another region for the formation of the intermediate layer halocline is the northern part of the Barents Sea where cold and fresh waters spreading by the Arctic Circumpolar Boundary Current far to the east (up to the Canada Basin) are formed. In the central and eastern part of the Barents Sea, there is a transformation of the Atlantic waters entering the Barents Sea from the Norwegian Sea. In the central and eastern parts of the Barents Sea a transformation of the Atlantic waters (which come from the Norwegian Sea with the Barents Sea branch) takes place. The outflow of these waters (which are colder, fresher and more stratified than the ones of the Fram Strait) through the St. Anna Trough is considered in the literature as a significant contribution to the thermohaline structure and general vorticity of the Arctic Basin cyclonic circulation. Significant sea area which is free from ice provides year-round use of operational satellite information for calculations.

The Pacific Ocean waters flowing into the Chukchi Sea from the Bering Strait in two streams form the upper part of the intermediate layer halocline in the Amerasian Basin. Here the most complex halocline structure in the form of the Atlantic and the Pacific waters combination vertically separated from each other by the halostad is formed. If the differences in the halocline characteristics in the Atlantic waters are due to the ones in oceanographic conditions in the Barents Sea and the Nansen Basin open waters, the characteristics of the Pacific Ocean halocline features (winter and summer modifications of the Bering Sea waters) are caused by seasonal variability in the Chukchi Sea. The processes of this water mass summer modification formation due to the absence of ice cover can be monitored by satellite means. The data on distribution of the Canada Basin main water masses can be obtained by CTD-buoys only. Temperature-profiling drifters can monitor only the summer modification of the Bering Sea waters as its lower boundary is at $50-60$ $m$ depth. Like in the Barents Sea, the inflow of the Pacific Ocean waters through the Chukchi Sea is considered as a significant contribution to the thermohaline structure and general vorticity of the basin circulation.

One more important process affecting the thermohaline structure of the basin waters is the outflow of marginal seas shelf freshened waters into the ocean. It is the most pronounced in the Laptev Sea where (in addition to the Lena River runoff) the main part of the Ob, the Yenisei, the Taz waters and the ones of other rivers get from the Kara Sea through the Vilkitsky Strait. The absence of operational information on the salinity greatly complicates not only the reproduction of surface halocline and cross-shelf exchange characteristics, but also the assessment of the formation of the basin's own deep waters, which is associated with the process of dense waters dipping along the continental slope. In the future, drifters with conductivity sensors or new satellite scanners of the Aquaris type, which have low accuracy and spatial resolution of $100 \mathrm{~km}$ so far, may become the main source of information on surface salinity.

The spatial scale of synoptic movements in the World Ocean sharply decreases from the low latitudes to the high ones [20]. The Rossby radius in the Eurasian and Amerasian Basins is $8-12 \mathrm{~km}$ for the Arctic region and 2-3 km for the marginal seas [21], which is confirmed by instrumental observations of vortices [22]. In this 22 
connection, the question arises of the insufficient spatial resolution of the available altimetric information $(14 \mathrm{~km})$ in the seas of the Arctic Ocean, which requires a careful analysis of the specific practical goals of the operational forecast system and the determination of optimal spatial-temporal scales.

Conclusion. Forecasting of oceanographic characteristics in the Arctic Basin of the Arctic Ocean is an extremely difficult problem requiring the consideration of much larger (in comparison with other regions of the World Ocean) number of physical processes in the conditions of extreme shortage of operational information.

Certain optimism in achieving acceptable results of forecasting system operation is inspired by the fact that key oceanographic areas affecting the entire basin (eastern part of the Norwegian and Greenland seas, the Barents Sea, the Chukchi Sea with the Bering Strait) are partly or completely free from ice and are significantly better provided with operational information.

Prospects for improving the capabilities of the monitoring and forecasting system in the Arctic are in involving of the sea transport on the Northern Sea Route to the Voluntary Observing Ship program, the rapid development of satellite sensors for determining salinity and the increase in the number of probing and profiling CTD-buoys.

Acknowledgements. The research was carried out within the framework of State Order No. 0827-2015-0001 "Fundamental research of the processes in the ocean - atmosphere - lithosphere system determining spatial-temporal variability of the global and regional scale environment and climate”.

\section{REFERENCES}

1. Proshutinsky, A., Yang, J., Krishfield, R., Gerdes, R., Karcher, M., Kauker, F., Koeberle, C., Hakkinen, S., Hibler, W., Holland, D., Maqueda, M., Holloway, G., Hunke, E., Maslowski, W., Steele, M. and Zhang, J., 2005. Arctic Ocean Study: Synthesis of Model Results and Observations. Eos Trans. AGU, [e-journal] 86(40), pp. 368-371. doi:10.1029/2005EO400003

2. Aksenov, Y., Ivanov, V.V., Nurser, A.J.G., Bacon, S., Polyakov, I.V., Coward, A.C., NaveiraGarabato, A.C. and Beszczynska-Moeller, A., 2011. The Arctic Circumpolar Boundary Current. J. Geophys. Res., [e-journal] 116(C9), C09017. doi:10.1029/2010JC006637

3. Aksenov, Y., Bacon, S., Coward, A.C. and Nurser, A.J.G., 2010. The North Atlantic Inflow to the Arctic Ocean: High-resolution Model Study. J. Mar. Syst., [e-journal] 79(1-2), pp. 1-22. doi:10.1016/j.jmarsys.2009.05.003

4. Golubeva, E.N., Platov, G.A. and Yakshina, D.F., 2015. Chislennoe Modelirovanie Sovremennogo Sostoyaniya Vod i Morskogo L'da Severnogo Ledovitogo Okeana [Numerical Simulations of the Current State of Waters and Sea Ice in the Arctic Ocean]. Led i Sneg, [ejournal] 55(2), pp. 81-92. http://dx.doi.org/10.15356/2076-6734-2015-2-81-92 (in Russian).

5. Platov, G.A., 2011. Numerical Modeling of the Arctic Ocean Deepwater Formation: Part II. Results of Regional and Global Experiments. Izvestiya, Atmospheric and Oceanic Physics, [ejournal] 47(3), pp. 377-392. doi:10.1134/S0001433811020083 (in Russian).

6. ARGO. Argo data selection. [online] Available at: http://www.argodatamgt.org/Access-todata/Argo-data-selection [Accessed 20 November 2016].

7. International Arctic Buoy Programme. Daily Table. Arctic Buoy Data. [online] Available at: http://iabp.apl.washington.edu/maps_daily_table.html [Accessed 22 November 2016]. 
8. UpTempO. Measuring the Upper layer Temperature of the Polar Oceans. [online] Available at: http://psc.apl.washington.edu/UpTempO/Data.php [Accessed 20 November 2016].

9. NOAA. National Centers for Environmental Information. [online] Available at: https://www.ncdc.noaa.gov/data-access/marineocean-data/vosclim/data-management-and-access [Accessed 20 November 2016].

10. GOSUD. Web Access. [online] Available at: http://www.gosud.org/Data-access/Web-access [Accessed 2 November 2016].

11. Nansen, F., 1902. Oceanography of the North Polar Basin. The Norwegian North Polar Expedition 1893-1896. Scientific Results. New York: Greenwood Press. Vol. 3 (9), 427 p.

12. Timofeev, V.T., 1960. Vodnye Massy Arkticheskogo Basseyna [Water Masses of the Arctic Basin]. Leningrad: Gidrometeoizdat, 191 p. (in Russian).

13. Nikiforov, E.G. and Shpaykher, A.O., 1980. Zakonomernosti Formirovaniya Krupnomasshtabnykh Kolebaniy Gidrologicheskogo Rezhima Severnogo Ledovitogo Okeana [Regularities in the Formation of Large-Scale Variations in the Hydrological Regime of the Arctic Ocean]. Leningrad: Gidrometeoizdat, 269 p. (in Russian).

14. Rudels, B., Jones, E.P., Schauer, U. and Eriksson, P., 2004. Atlantic Sources of the Arctic Ocean Surface and Halocline Waters. Polar Res., [e-journal] 23(2), pp. 181-208. doi:10.3402/polar.v23i2.6278

15. Rudels, B., 2012. Arctic Ocean Circulation and Variability - Advection and External Forcing Encounter Constraints and Local Processes. Ocean Sci., [e-journal] 8(2), pp. 261-286. doi:10.5194/os-8-261-2012

16. Steele, M., Morison, J., Ermold, W., Rigor, I., Ortmeyer, M. and Shimada, K., 2004. Circulation of Summer Pacific Halocline Water in the Arctic Ocean. J. Geophys. Res., 109(C2), C02027. doi:10.1029/2003JC002009

17. Swift, J.H., Jones, E.P., Aagaard, K., Carmack, E.C., Hingston, M., MacDonald, R.W., McLaughlin, F.A. and Perkin, R.G., 1997. Waters of the Makarov and Canada Basins. DeepSea Res. II., [e-journal] 44(8), pp. 1503-1529. doi:10.1016/S0967-0645(97)00055-6

18. Ivanov, V.V., Polyakov, I.V., Dmitrenko, I.A., Hansen, E., Repina, I.A., Kirillov, S.A., Mauritzen, C., Simmons, H. and Timokhov, L.A., 2009. Seasonal Variability in Atlantic Water off Spitsbergen. Deep-Sea Res. I, [e-journal] 56(1), pp. 1-14. doi:10.1016/j.dsr.2008.07.013

19. Schauer, U., Rudels, B., Jones, E.P., Anderson, L.G., Muench, R.D., Björk, G., Swift, J.H., Ivanov, V. and Larsson, A.-M., 2002. Confluence and Redistribution of Atlantic Water in the Nansen, Amundsen and Makarov Basins. Ann. Geophys., [e-journal] 20(2), pp. 257-273. doi:10.5194/angeo-20-257-2002

20. Chelton, D.B., Schlax, M.G. and Samelson, R.M., 2011. Global Observations of Nonlinear Mesoscale Eddies. Progr. Oceanogr., [e-journal] 91(2), pp. 167-216. doi:10.1016/j.pocean.2011.01.002

21. Nurser, A.J.G. and Bacon, S., 2014. The Rossby Radius in the Arctic Ocean. Ocean Sci., [e-journal] 10(6), pp. 967-975. doi:10.5194/os-10-967-2014

22. Manley, T.O. and Hunkins, K., 1985. Mesoscale Eddies of the Arctic Ocean. J. Geophys. Res., [e-journal] 90(C3), pp. 4911-4930. doi:10.1029/JC090iC03p04911 